\title{
Wyniki realizacji programów restrukturyzacji górnictwa węgla kamiennego po 1989 r.
}

Procesy restrukturyzacji przemysłu pociągają za sobą konieczność przystosowanie się poszczególnych firm i gałęzi do nowych warunków. Szczególnie trudna sytuacja zaznacza się w przemyślę węglowym, a w reformowaniu tej gałęzi występuje wiele trudności. Przedmiotem niniejszej analizy jest zaprezentowanie wyników działań związanych z reformowaniem górnictwa węgla kamiennego w wyniku wdrażania kolejnych programów naprawczych.

Punktem wyjścia oceny programów restrukturyzacji górnictwa węgla kamiennego, była sytuacja tego sektora na początku okresu transformacji polskiej gospodarki.

Do głównych problemów zaliczono:

1. Niedostosowanie logistyczne do nowych warunków ekonomicznych. Na początku lat 90-tych, w zetknięciu się z ograniczonym popytem i konkurencją na rynku krajowym, sektor wykazywał niemożność realizacji preferencji konsumentów. Chodziło szczególnie o powiązanie wysokości ceny węgla z jego jakością, poprawy dystrybucji i elastyczności cenowej.

2. Nadmierny potencjał produkcyjny górnictwa. Spośród mierników obrazujących potencjał górnictwa, zatrudnienie na koniec 1989 r. przekroczyło 415 tys., a zdolności wydobywcze kopalń wynosiły ponad $180 \mathrm{mln}$ ton. Pod koniec lat 80-tych opracowano rządową (Ministerstwa Przemysłu i Handlu) prognozę popytową na węgiel kamienny do końca lat 90-tych. Prognoza zakładała warianty potencjalnego zbytu węgla przy określonych warunkach popytu krajowego i zagranicznego. Prognoza popytowa w wariancie optymistycznym zakładała sprzedaż węgla w wysokości $107 \mathrm{mln}$ ton, a w wariancie pesymistycznym, około $90 \mathrm{mln}$ ton. Przyjmując za punkt wyjścia przytoczone prognozy, nadmierne zdolności wydobywcze na początku lat 90 -tych wynosiły dla wariantu optymistycznego około $70 \mathrm{mln}$ ton, dla wariantu pesymistycznego około $90 \mathrm{mln}$ ton.

3. Niską wydajność pracy w górnictwie węgla kamiennego. W 1989 r. wskaźnik wydajności wynosił 429 ton na 1 zatrudnionego. Jeśli przyjąć zakładane wskaźniki wydobycia, gwarantujące opłacalność wydobycia węgla w wysokości 607 ton na 1 zatrudnionego, to zatrudnienie w 1989 powinno wynosić 293 tys.. Oznacza to, że przerost zatrudnienia w górnictwie węgla kamiennego w 1989 r. wynosił 122 tys. Pracowników, a w konsekwencji w 2000 r. zatrudnienie w kopalniach węgla kamiennego, przy wydobyciu $107 \mathrm{mln}$ ton powinno wynosić 176 tys. górników, a przy wydobyciu $90 \mathrm{mln}$ ton - 148 tys. Wy- 
nika z tego, że do roku 2000 z górnictwa węgla kamiennego winno odejść, zakładając wyższe wydobycie - 239 tys. osób, przy niższym wydobyciu - 267 tys.

4. Przestarzałe i zuźyte wyposażenie techniczne kopalń. W przemyśle węgla kamiennego zużycie maszyn, urządzeń technicznych i narzędzi wynosiło w 1989 r. prawie $55 \%$.

5. Utrata od 1989 r. płynności finansowej. W 1989 r. ujemny wynik finansowy brutto wyniósł ponad $43 \mathrm{mln}$ zł, w 1990 r. pomimo uwolnienia cen węgla deficyt ten wzrósł do ponad $41 \mathrm{mln} \mathrm{z}$, a w $1991 \mathrm{r}$. wynik finansowy netto przekroczył $350 \mathrm{mln} \mathrm{zl}$. W wymienionych latach górnictwo otrzymywało dotacje przedmiotowe $\mathrm{z}$ budżetu państwa $\mathrm{w}$ wysokości, w 1989 r. - 332 mln zł, w 1990 r. - 910 mln zł, w 1991 r. 508 mln zł. Ponadto dodatkowe zobowiązania i należności górnictwa w stosunku do podmiotów gospodarczych i budżetu państwa wynosiły w 1990 r. $438 \mathrm{mln}$ zł oraz $806 \mathrm{mln}$ w 1991 r. Górnictwo węgla kamiennego na początku lat 90-tych było bankrutem.

6. Ogromne potrzeby kapitałowe (około $3 \mathrm{mld}$ zł.) na pokrycie szkód górniczych i likwidowanych kopalń i ponad $4 \mathrm{mld}$ zł na podtrzymanie dalszego wydobycia węgla, tj. odtworzenie i modernizacja wyposażenia technicznego.

7. Nieracjonalna organizacja wewnętrzna kopalń oraz duża ilość komórek pomocniczych i socjalnych. Kopalnie były właścicielami klubów sportowych, szkół górniczych, domów kultury, szpitali, sklepów, domów wczasowych, domów mieszkalnych, wyciągów narciarskich, hoteli, ośrodków wczasowych i in.

8. Wadliwy model zarządzania przedsiębiorstwa państwowego z silną radą pracowniczą i jeszcze silniejszymi związkami zawodowymi. Cele związków zawodowych i rady pracowniczej były i są przeciwne w stosunku do celów przedsiębiorstwa funkcjonującego w gospodarce rynkowej.

\section{ETAPY RESTRUKTURYZACJI SEKTORA WĘGLOWEGO W LATACH 1990-2000}

W latach 90-tych systematycznie pogarszała się jego sytuacja finansowa górnictwa węgla kamiennego. W roku 1990 zobowiązania kopalń przekroczyły 0,4 mld zł, a w roku 1995 przekroczyły 5 mld zł, był to ponad 10 krotny wzrost zadłużenia w okresie 5 lat. Zła sytuacja finansowa górnictwa będąca konsekwencją wspomnianych wcześniej przyczyn wymusiła zmiany. W latach 1990-2000 rozpoczęto proces restrukturyzacji górnictwa węgla kamiennego, który od 1993 r. realizowany był w oparciu o założenia ekonomiczno-społeczne programów restrukturyzacji zatwierdzanych przez Komitet Ekonomiczny Rady Ministrów (KERN).

Realizację pierwszego programu rozpoczęto w 1993 r., a drugi program restrukturyzacji przypadl na lata 1993-1994, trzeci program przeprowadzano w latach 1994-1995, czwarty program obejmuje lata 1996-1998, a piąty program zaplanowano na lata 1998-2002.

Przemiany gospodarcze w Polsce po 1989 r. w górnictwie węgla kamiennego rozpoczęto od restrukturyzacji zarządzania tym sektorem. W 1990 r. zlikwidowano struktury nadzorujące kopalnie (4 Przedsiębiorstwa Eksploatacji Węgla Kamiennego), zaprzestała funkcjonować Wspólnota Węgla Kamiennego, która była powołana w miejsce wcześniej zlikwidowanego Ministerstwa Górnictwa i Energetyki. Kopalnie węgla kamiennego stały się samodzielnymi przedsiębiorstwa państwowymi, bez tzw. „czapki” czyli nadzoru struktur nadrzędnych. Organem założycielskim był Minister Przemysłu i Handlu. 
Ten kierunek przemian zakładał, że kopalnie węgla kamiennego będą funkcjonowały jako jednostki samodzielne $\mathrm{z}$ samorządowym modelem zarządzania, formule $3 \mathrm{~S}$ (samozarządzający, samorządny, samofinansujący. Po trzech latach ocena tego modelu jest negatywna. Wynika ona z różnicy celów dyrekcji, rady pracowniczej i bardzo silnych związków zawodowych w zakresie zarządzania.

Samodzielność kopalń w tym czasie związana byłą również z możliwością swobodnego handlu węglem w kraju i zagranica. Samodzielność w tym zakresie nie trwała jednak długo. Od grudnia 1990 r. do lipca 1992 r. kopalnie utraciły samodzielność w zakresie eksportu węgla. Z ekonomicznego punktu widzenia było to uzasadnione. Eksportowany węgiel sprzedawany był poniżej ceny krajowej, a także poniżej opłacalności ekonomicznej kopalń. Ograniczono także swobodę kształtowania cen węgla. Od czerwca 1990 r. przez dwa lata kopalnie były zobowiązane do każdorazowego powiadamiania izb skarbowych o zamiarze podwyższania cen węgla.

Pomimo regulacji cen węgla i ograniczenia eksportu, kopalnie, w wyniku nadprodukcji węgla, konkurowaly w obniżaniu cen pomiędzy sobą. Spowodowalo to gwaltowne pogorszenie się sytuacji finansowej kopalń i gwaltownego przyrostu zadłużenia. W latach 1990-1992 zadlużenie kopalń wzroslo z $438 \mathrm{mln}$ zl do $2119 \mathrm{mln}$ zl, czyli prawie 5 - krotnie.

Szybko pogarszająca się sytuacja ekonomiczna kopalń, wymusiła podjęcie kolejnych zmian. Na początku 1993 roku KERN zatwierdził „I Program restrukturyzacji węgla kamiennego - realizacja I etapu w 1993 roku w ramach możliwości finansowych państwa”.

Pierwszy program restrukturyzacji (1993 r.) przeprowadzany byl w początkowych latach transformacji polskiej gospodarki. Zakladal 1 marca 1993 r. utworzenie 6 spólek węglowych, jako jednoosobowych spólek akcyjnych (S.A.) Skarbu Państwa grupujących 51 kopalń, od 1 lipca utworzenie Katowickiego Holding handlowy - jako jednoosobowej spólki akcyjnej Skarbu Państwa grupującej 11 kopalń.

Program utworzenia 7 spółek akcyjnych, grupujących samodzielne do tej pory przedsiębiorstwa, ponadto powiązane ze sobą tylko statutem S.A., co z punktu widzenia powiązań prawno-ekonomicznych i organizacyjnych nie było najlepsze. Szybko okazało się, że sytuacja finansowa spółek nadal pogarsza się. Na koniec 1993 r. zadłużenie górnictwa wynosiło już 3,5 mld zł i było o $68 \%$ wyższe aniżeli w 1992 roku.

Zła sytuacja finansowa górnictwa węgla kamiennego wymusiła opracowanie nowego programu restrukturyzacji.

Drugi program został zatwierdzony przez KERM 1 września 1993 r. pod nazwą „Program powstrzymania upadłości górnictwa węgla kamiennego w Polsce”. Program ten miał być realizowany do końca 1993 r. Jedynym celem było powstrzymanie rosnącego zadłużenia finansowego kopalń i zahamowania ich spadku efektywności. W niewielkim stopniu udało się zahamować spadek efektywności kopalń, a zadłużenie ich nadal rosło.

Program ten nie przyniósł trwałej poprawy sytuacji finansowej, nie wpłynął na wzrost wskaźników efektywności spółek.

W marcu 1994 r. zatwierdzono trzeci program restrukturyzacji, pt. „Restrukturyzacja górnictwa węgla kamiennego. Program dla realizacji II etapu w okresie 1994-1995". Był to pierwszy program w którym określono politykę państwa wobec górnictwa węgla kamiennego.

W programie założono:

1. likwidację nierentownych kopalń i ponoszenie przez państwo kosztów likwidacji, 
2. łączenie kopalń węgla w efektywne jednostki organizacyjne

3. uwolnienie cen węgla na rynku krajowym,

4. zlikwidowanie dotacji przedmiotowych do produkcji węgla,

5. uzyskanie rentowności górnictwa węgla.

De facto, po raz pierwszy w powojennej historii resortu górnictwa założono możliwość postawienia w stan upadłości poszczególnych kopalń. Wprawdzie nierentowne kopalnie mogły jeszcze funkcjonować w spółkach węglowych. liczył się bowiem wynik finansowy spółek.

W początkowej fazie przystapiono do łączenia kopalń nierentownych z kopalniami będącymi w lepszej sytuacji. W latach 1994-1995 procesem koncentracji objęto 12 zakładów (Centrum i Szombierki, Polska i Nowy Wirek, Pokój i Wawel, Jastrzębie i Moszczenica, Chwałowice i Rymer, 1 Maja i Marcel) tworząc 6 nowych kopalń.

Pomimo zmian organizacyjno-produkcyjnych sytuacja finansowa górnictwa nie poprawiła się. Wprawdzie 5 z 7 spółek węglowych uzyskało dodatni wynik finansowy, ale łączne saldo zobowiązań i należności sektora wzrosło o $0,5 \mathrm{mld}$ zł w stosunku do $1993 \mathrm{r}$. Podobnie było w roku następnym, 3 z 7 spółek miały dodatni wynik finansowy netto, a zadłużenie sektora węglowego wzrosło o 0,2 mld zł i wynosiło w 1995 r. 5,1 mld zł.

W kwietniu 1996 r. KERM przyjął założenia do czwartego programu restrukturyzacji górnictwa węgla kamiennego, zatwierdzonego 24 stycznia 1997 r. przez Sejm RP. Podstawowym celem programu było „odwrócenie postępującego procesu degradacji tego sektora” $\mathrm{i}$,osiągnięcie dodatniego wyniku finansowego już w 1998 roku”.

W programie założono do realizacji sześć szczegółowych celów.

1. Systematyczne ograniczanie zdolności produkcyjnych kopalń. Poziom wydobycia węgla w latach 1996-1998 będzie się systematycznie zmniejszał.

Z założeń programu wynikało, że w latach 1996-1998 nastąpi ograniczenie zdolności wydobycia węgla kamiennego o około $10 \mathrm{mln}$ ton (tab. 1). W programie założono także, że sprzedaż węgla na rynek krajowy wynosić będzie średnio $98 \mathrm{mln}$ ton, a eksport będzie systematycznie zmniejszany.

Tabela 1. Poziom wydobycia węgla kamiennego

\begin{tabular}{|l|c|c|c|c|c|}
\hline \multicolumn{1}{|c|}{ wyszczególnienie } & 1996 & 1997 & 1998 & 1999 & 2000 \\
\hline Zakładane wydobycie węgla w mln t & 130 & 128 & 126 & 123 & 120 \\
\hline wielkość wydobycia węgla w mln t & 138 & 138 & 116 & 109 & 102 \\
\hline realizacja (różnica + - w mln t) & +8 & +8 & -10 & -14 & 18 \\
\hline eksport w mln t & 28,9 & 29,5 & 27,7 & 24,1 & 23,0 \\
\hline
\end{tabular}

Źródło: Rocznik statystyczny 2000. GUS. Warszawa

Rzeczpospolita. 4.XII. 2001.

2. Zmniejszanie zatrudnienia w sektorze wiązano ze wzrostem wydajności pracy i poprawy wyniku finansowego kopalń. Założono, że do 1998 r. zatrudnienie w górnictwie zmniejszy się o 80 tys. pracowników.

3. Wzrost wydajności pracy w górnictwie określała restrukturyzacja techniczna.(tab. 2) Do 2000 r. wydajność na 1 zatrudnionego miała wzrosnąć z 500 t, do minimum 615 t. Kolejnym elementem restrukturyzacji technicznej miała być likwidacja 8 kopalń (BarbaraChorzów, Siemianowice, Pstrowski, Paryż, Sosnowiec, Jowisz, Saturn oraz wszystkie 
kopalnie Wałbrzyskiego Zagłębia Węglowego. Zamierzano połączyć kolejnych 6 zakładów w 3 kopalnie (Katowice i Kleofas, Niwka-Modrzejów i Jan Kanty, Miechowice i Bobrek) i przeprowadzić proces łączenia organizacyjnego i technicznego w pozostałych nierentownych kopalniach.

Tabela 2. Restrukturyzacja zatrudnienia i wydajności pracy (na koniec roku)

\begin{tabular}{|l|c|c|c|c|c|}
\hline Wyszczególnienie & 1996 & 1997 & 1998 & 1999 & 2000 \\
\hline Zatrudnienie w tys. osób & 259,1 & 243,3 & 207,9 & 173,6 & 155,0 \\
\hline Wielkość wydobycia węgla w mln ton & 137,9 & 137,8 & 116,0 & 109,2 & 102,2 \\
\hline Średnia wydajność: w tonach na 1 zatrudnionego & 532 & 566 & 578 & 629 & 658 \\
\hline $\begin{array}{l}\text { Średnia wydajność: w tonach na pracowniko- } \\
\text { dniówkę }\end{array}$ & 2,6 & 2,9 & 2,7 & 3,0 & 3,3 \\
\hline $\begin{array}{l}\text { Planowane zmniejszenie zatrudnienie wg. Założeń } \\
\text { programu restrukturyzacji w tys. }\end{array}$ & $\mathrm{x}$ & $\mathrm{x}$ & 24,3 & 29,6 & 28,0 \\
\hline Realizacja (odejścia) w tys. Osób & 14,2 & 14,5 & 35,4 & 34,3 & 18,6 \\
\hline
\end{tabular}

Źródło: Rzeczpospolita 4. XII. 2001.

4. Restrukturyzacja zobowiązań kopalń wobec ZUS oraz Narodowego i Wojewódzkich funduszy Ochrony Środowiska i Gospodarki Wodnej. Regulacja zobowiązań miała nastąpić na drodze częściowej restrukturyzacji zobowiązań, rozumianej jako częśsiowe umorzenie zadłużenia kopalń wobec podmiotów. Spłata pozostałej części zobowiązań miała być realizowana ze środków uzyskanych ze sprzedaży węgla, którego cena miała być podniesiona, oraz dotacji budżetu państwa (5,3 mld zł).

Oznaczało to, że górnictwo węgla kamiennego, z prawnego punktu widzenia, znalazło się na drodze „układowej” z wierzycielami, jest niewypłacalne i jest na skraju bankructwa.

5. Rozpoczęcie procesu prywatyzacji kopalń. Pierwsze kopalnie wyznaczone do prywatyzacji to „Budryk” w Rybnickim Okręgu Węglowym i „Bogdanka” w Lubelskim Zagłębiu Węglowym.

Kolejny piąty program restrukturyzacji górnictwa przyjęty zostal przez Radę Ministrów RP 30 czerwca 1998 r. pt. „Reforma górnictwa węgla kamiennego w Polsce w latach 1998-2002" W dniu 15 grudnia 2000 r. Sejm RP znowelizowal ustawę z dnia 26 listopada 1998 r., wspierającą program restrukturyzacji górnictwa węgla.

Cele programu restrukturyzacji obejmowały:

1. Dostosowanie podmiotów gospodarczych w górnictwie węgla kamiennego do funkcjonowania w warunkach gospodarki rynkowej,

2. Utrzymanie konkurencyjności polskiego węgla na rynku krajowym.

3. Najpóźniej do 2001 roku spółki węglowe nie będą ponosiły strat ze sprzedaży węgla.

4. Najpóźniej do 2002 r. spółki węglowe osiągną próg rentowności, dodatni wynik finansowy netto. Nastąpi samofinansowanie się spółek węglowych i bieżąca regulacja swoich zobowiązań. 


\section{WYNIKI WDRAŻANIA PROGRAMÓW RESTRUKTURYZACJI}

\section{Eksploatacja i zbyt węgla kamiennego}

Wydobycie węgla kamiennego w latach 1989-2000 zmniejszyło się o 57,4\%, ze 178,0 mln ton do $102,2 \mathrm{mln}$ ton. Potencjał produkcyjny górnictwa zmniejszył się o ponad $70 \mathrm{mln}$ ton. W tym zakresie w pełni zrealizowano założenia programów restrukturyzacji (tab. 3).

Sprzedaż węgla kamiennego na rynku krajowym i eksporcie charakteryzowała się dużym spadkiem. W 1989 r. wyniosła około $174 \mathrm{mln}$ ton., z tego $145,1 \mathrm{mln}$ ton sprzedano w kraju i 28,9 mln ton na eksport (16,6\%). W latach 1990-1992 nastapił dalszy spadek sprzedaży węgla do $126,2 \mathrm{mln}$ ton, $\mathrm{z}$ tego udział rynku krajowego wyniósł $107,5 \mathrm{mln}$ ton $(85,2 \%)$ i 18,7 mln ton na eksport. Łączny spadek sprzedaży węgla na rynku krajowym wyniósł $48,7 \mathrm{mln}$ ton, tj. $27,5 \%$, a spadek sprzedaży eksportowej wyniósł 10,2 min ton, tj. $35,3 \%$. W latach 1993-1997 nastąpiła stabilizacja sprzedaży węgla na poziomie 129-133 mln ton na rok.

Rok 1998 był przełomowym, rozpoczął się gwałtowny spadek sprzedaży węgla kamiennego. W roku 2000 sprzedaż wyniosła $101,0 \mathrm{mln}$ ton, z tego $78,0 \mathrm{mln}$ ton na rynku krajowym i 23,0 mln tom na eksport. W ciągu 3 lat (1998-2000) sprzedano o 31,6 mln ton węgla mniej, tj. o 23,8\%. Na rynku krajowym sprzedano mniej o 24,0 mln ton, tj. o 23,5\%, a w eksporcie o $7,6 \mathrm{mln}$ ton mniej, tj. o $24,8 \%$.

Sprzedaży węgla na rynku krajowym była o 20,0 mln ton niższa od założeń programu restrukturyzacji. W niewielkim stopniu zmniejszył się także eksport węgla.

Tabela 3. Wydobycie i eksport węgla kamiennego

\begin{tabular}{|l|c|c|c|c|}
\hline L.p. & Rok & $\begin{array}{c}\text { wydobycie } \\
(\text { w mln } \mathrm{t})\end{array}$ & eksport (w mln t) & $\begin{array}{c}\text { udzial eksportu } \\
\text { w wydobyciu }(w \%)\end{array}$ \\
\hline 1 & 1952 & 84,4 & 24,2 & 28,7 \\
\hline 2 & 1960 & 104,0 & 17,5 & 16,8 \\
\hline 3 & 1970 & 140,0 & 28,8 & 20,6 \\
\hline 4 & 1975 & 172,0 & 38,3 & 22,3 \\
\hline 5 & 1979 & 201,0 & 41,4 & 20,6 \\
\hline 6 & 1985 & 192,0 & 36,0 & 18,7 \\
\hline 7 & 1989 & 178,0 & 28,7 & 16,1 \\
\hline 8 & 1990 & 147,4 & 28,0 & 19,0 \\
\hline 9 & 1991 & 140,1 & 18,0 & 12,8 \\
\hline 10 & 1992 & 131,3 & 19,6 & 14,9 \\
\hline 11 & 1993 & 130,3 & 23,0 & 17,6 \\
\hline 12 & 1994 & 132,7 & 28,0 & 21,1 \\
\hline 13 & 1995 & 135,3 & 31,9 & 23,6 \\
\hline 14 & 1996 & 136,2 & 28,9 & 21,2 \\
\hline 15 & 1997 & 137,1 & 29,5 & 21,5 \\
\hline 16 & 1998 & 116,0 & 27,7 & 23,9 \\
\hline 17 & 1999 & 109,2 & 24,1 & 22,1 \\
\hline 18 & 2000 & 102,2 & 23,0 & 22,5 \\
\hline
\end{tabular}

Źródło: Rocznik statystyczny 1980, 2000. GUS. Warszawa. 


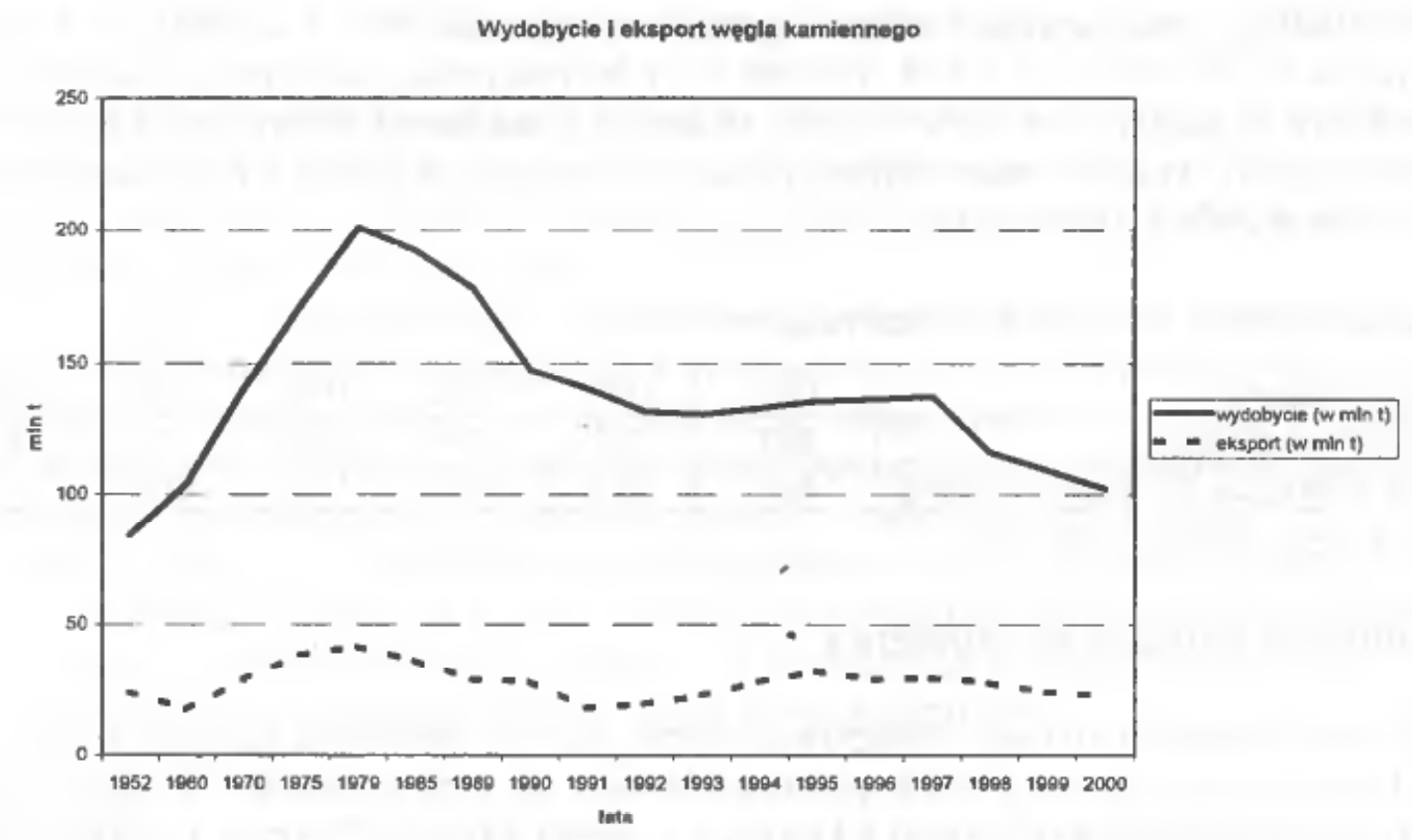

\section{Zatrudnienie}

W latach 1989-2000 zatrudnienie w górnictwie węgla kamiennego zmniejszyło się o 260,0 tys. pracowników, tj. o 62,7\% i wykazując zróżnicowane tempo. W latach 1989-1992 rocznie odchodziło z górnictwa około 25,0 tys. osób, tzn. w ciągu 3 lat zatrudnienie obniżyło się o 74,8 tys. osób, tj. o $18,0 \%$. Wysoki spadek zatrudnienia osiągnięto tylko na skutek naturalnych odejsć pracowników z pracy i przy bardzo niskim poziomie zatrudniania nowych pracowników.

Wysokie tempo spadku zatrudnienia utrzymywało się w kolejnych dwóch latach (1993-1994). Zatrudnienie zmniejszyło się o 51,7 tys. osób, tj. o $15,1 \%$. W następnych latach tempo zmniejszania zatrudnienia było niższe, łącznie odeszło $\mathrm{z}$ pracy 45,1 tys. pracowników. W latach 1998-1999 w wyniku zastosowania instrumentów Górniczego Pakietu Socjalnego, nastąpiło wyraźne zwiększenie odejść z pracy. Łączny spadek zatrudnienia w dwóch latach wyniósł 69,7 tys. osób. W 2000 r. spadek zatrudnienia wyniósł dalsze 18,6 tys. pracowników.

Tak wysoki spadek zatrudnienia w górnictwie węgla kamiennego był możliwy, tylko w skutek nie przyjmowania nowych pracowników do pracy w kopalniach i zastosowania Górniczego Pakietu Socjalnego. Z pakietu socjalnego skorzystało do końca 2001 r. 64,7 tys. pracowników sektora górniczego.

\section{Koncentracja produkcji}

Zmniejszanie zatrudnienia w kopalniach było możliwe miedzy innymi dzięki koncentracji produkcji. Nastąpiło zmniejszenie liczby czynnych ścian, wzrost wydobycia węgla $\mathrm{z}$ jednej ściany. 
W 1989 r. liczba czynnych ścian w górnictwie wynosiła 861, a w 2000 r. ich liczba zmniejszyła się do 183, czyli o 678. W 1989 r. średnio na jedną ścianę przypadało 207 tys. ton wydobytego węgla, to w 2000 r. średni wskaźnik przekroczył 550 tys. ton i był prawie 3 krotnie wyższy. Wzrosło także wydobycie dobowe węgla z 1 ściany z 863 ton w 1989 r. do 2473 ton w 2000 r. (tabela 4).

Tabela 4. Wybrane wskaźniki koncentracji produkcji

\begin{tabular}{|l|c|c|c|c|c|c|}
\hline Wyszczególnienie & 1989 & 1991 & 1992 & 1995 & 1998 & 2000 \\
\hline liczba czynnych ścian & 861 & 702 & 654 & 415 & 259 & 183 \\
\hline Średnie wydobycie z I ściany w t/dobę & 863 & 918 & 962 & 1470 & 1929 & 2473 \\
\hline
\end{tabular}

Źródło: Rzeczpospolita 4. XII. 2001.

\section{Zadlużenie i dotacje dla górnictwa}

W analizowanym okresie następował szybki wzrost zadłużenia górnictwa (tab. 5). Straty finansowe ponoszone przez kopalnie cechowały się dużą dynamiką. W latach 1990-1992 przyrost zadłużenia był ponad 4 krotny, a w latach 1993-1997 ponad 3 krotny a łączna suma zobowiązań przekroczyła $10 \mathrm{mld}$ zł. Pomimo wdrażania programów restrukturyzacji zadłużenie kopalń bardzo szybko rosło, osiągając w 2000 r. wartość ponad 19 mld zł. Wskazuje to na niepowodzenie stosowanych w programach restrukturyzacji, mechanizmów naprawczych.

Restrukturyzacja finansowa gómictwa zakłada umorzenie kopalniom około $10 \mathrm{mld}$ zł wierzytelności, a pozostałą część długów kopalnie powinny spłacić w odroczonych terminach.

Program restrukturyzacji górnictwa wymagał ogromnych dotacji z budżetu państwa. W latach 1990-2000 dotacja wspierająca proces przemian w górnictwie przekroczyła 6,4 mld zł.

Tabela 5. Wynik finansowy górnictwa w latach 1989-2000 (mld zł)

\begin{tabular}{|l|c|c|c|c|c|c|c|c|c|c|c|c|}
\hline $\begin{array}{l}\text { Wyszcze- } \\
\text { gólnienie }\end{array}$ & 1989 & 1990 & 1991 & 1992 & 1993 & 1994 & 1995 & 1996 & 1997 & 1998 & 1999 & 2000 \\
\hline $\begin{array}{l}\text { Wynik } \\
\text { finansowy } \\
\text { netto }\end{array}$ & 0,034 & $-0,04$ & $-0,35$ & $-1,3$ & $-1,5$ & $-0,2$ & $-0,8$ & $-1,8$ & $-2,6$ & $-4,3$ & $-3,4$ & $-1,8$ \\
\hline $\begin{array}{l}\text { Zadłuże- } \\
\text { nie gór- } \\
\text { nictwa }\end{array}$ & 0 & $-0,5$ & $-0,8$ & $-2,2$ & $-3,5$ & $-3,9$ & $-5,7$ & $-7,3$ & $-10,2$ & $-13,2$ & $-17,3$ & $-19,2$ \\
\hline
\end{tabular}

Źródło: Rzeczpospolita. 4.XII.2001.

Doświadczenia programów restrukturyzacji wskazują na złożoność tego procesu, który wymaga ogromnego doświadczenia i wiedzy ekspertów przygotowujących go. Ważnym elementem programu jest właściwe przygotowanie odpowiednich narzędzi i środków finansowych na jego realizację. Przy jego konstrukcji należy uwzględnić, obok celów technicznych i ekonomicznych również cele społeczne.

Jak wskazują dotychczasowe doświadczenia w tym zakresie, przygotowanie i realizacja programów restrukturyzacji górnictwa węgla kamiennego, pomimo ogromnego wysiłku 
finansowego, budzi wiele zastrzeżeń i przysparza wątpliwości co do przyjętej metodologii działania.

Zastrzeżenia budzi dyrektywny charakter prognozy wydobycia węgla kamiennego. Nie jest powiązany z prognozą popytu na rynku węgla krajowego i międzynarodowego. Nakazowy charakter programów restrukturyzacji budzi zdziwienie, że zastosowano metodologię zmian rodem $\mathrm{z}$ minionej epoki.

Koniecznym jest zastosowanie mechanizmów rynkowych w uzdrawianiu sektora górniczego. Jeśli kopalnie nie realizują celów ekonomicznych, przynoszą straty należy stosować procedury ogólnie przyjęte w tym zakresie, tj. drogę prawną od układu do upadłości. Jeśli eksport jest nieopłacalny, dotowany przez budżet, należy zastosować mechanizmy ekonomiczne zmierzające do ograniczania zdolności wydobywczych kopalń.

Należy skończyć z działaniami ograniczającymi równość podmiotów wobec prawa, stosując odmienne kryteria dla kopalń, inne dla pozostałych podmiotów gospodarczych.

Niepokój budzą preferencje wynikające z Górniczego Pakietu Socjalnego, w uprzywilejowany sposób nagradzając odchodzących z pracy górników.

\section{Literatura}

Bochniarz H., Krajewski S., 1997. Sektorowe programy restrukturyzacji $i$ prywatyzacji majątku państwowego. (praca zbiorowa). Zespół zadaniowy ds. Polityki Strukturalnej w Polsce. Warszawa.

Dziennik Ustaw. 1990. nr 16, 51, 99.

Dziennik Ustaw. 1993. nr 17, 33..

Dziennik Ustaw. 1996. nr 157.

Dziennik Ustaw. 1997. nr 30.

Glikman P., Lipowski A., 1997. Przezwyciężenie dysproporcji makrostrukturalnych w okresie transformacji. [w:] Dynamika transformacji polskiej gospodarki. Warszawa.

Hare P., 1993. Polityka makroekonomiczna a polityka przemyslowa $w$ ksztaltowaniu branżowej $i$ regionalnej struktury gospodarki. [w:] Transformacja systemu gospodarczego w krajach Europy Środkowo-Wschodniej. Pod red. J. Czekaj. Warszawa.

Raport o stanie polskiego przemysłu za lata 1995-1996. MP i H.

Rocznik Statystyczny Przemysłu 2000. GUS. Warszawa.

Rzeczpospolita 4. XII. 2001.

Szpilewicz a. 1996. Stan i perspektywy przemystu węglowego w Polsce. [w:] Stan i perspektywy przemysłu węglowego w Polsce. Rada Strategii Społeczno-Gospodarczej przy Radzie Ministrów. Raport nr 15. Warszawa.

Suwała W., Kudełko M., Kamiński J. 2001. Rynek Węgla kamiennego w Polsce. Studia, Rozprawy, Monografic. Instytut Gospodarki Surowcami Mineralnymi i Energią. NR 95. PAN. Kraków. 